\title{
Antimicrobial and antioxidant activities of Saccharomyces cerevisiae IFST062013, a potential probiotic
}

\author{
Md. Fakruddin", Md. Nur Hossain and Monzur Morshed Ahmed
}

\begin{abstract}
Background: Probiotic yeast has become a field of interest to scientists in recent years.

Methods: Conventional cultural method was employed to isolate and identify yeast and standard methods were used to determine different probiotic attributes, antimicrobial and antioxidant properties.

Results: This study reports potential probiotic properties of a strain of S. cerevisiae IFST 062013 isolated from fruit. The isolate is tolerant to a wide range of temperature and $\mathrm{pH}$, high concentration of bile salt and $\mathrm{NaCl}$, gastric juice, intestinal environment, a-amylase, trypsin and lysozyme. It can produce organic acid and showed resistance against tetracycline, ampicillin, gentamycin, penicillin, polymixin B and nalidixic acid. It can assimilate cholesterol, can produce killer toxin, vitamin B12, glutathione, siderophore and strong biofilm. It showed moderate auto-aggregation ability and cell surface hydrophobicity. The isolate can produce enzymes such as amylase, protease, lipase, cellulose, but unable to produce galactosidase. The isolate can't produce gelatinase and DNase. The isolate showed moderate anti-microbial activity against bacteria and fungi and cell lysate showed better antimicrobial activity than whole cell and culture supernatant. Again, the isolate showed better anti-bacterial activity against gram negative bacteria than gram positive. The isolate showed strong antioxidant activity, reducing power, nitric oxide and hydroxyl radical scavenging activity, significant brine shrimp cytotoxicity and acute toxicity and metal ion chelating activity. The isolate did not induce any detectable change in general health of mice upon oral toxicity testing and found to be safe in mouse model. The isolate improve lymphocyte proliferation and cytokine production in treated mice.
\end{abstract}

Conclusions: Such isolate could be potential as probiotic to be used therapeutically.

Keywords: Saccharomyces, Anti-bacterial, Probiotic, Anti-oxidant, Immuno, Activity

\section{Background}

Probiotics are a group of organism those confer health benefit to consumers [1]. To be used as probiotic, an organism should possess several attributes such as adhesive ability, acid and $\mathrm{H}_{2} \mathrm{O}_{2}$ production ability [2], bile tolerance and significant antibacterial activity and immunomodulatory activity [3] and must be non-pathogenic $[4,5]$. Microorganisms that are probiotic to humans include yeasts, bacilli, Escherichia coli, enterococci, and the more commonly used bifidobacteria and lactic acid

\footnotetext{
* Correspondence: fakruddinmurad@gmail.com Industrial Microbiology Laboratory, Institute of Food Science and Technology (IFST), Bangladesh Council of Scientific and Industrial Research (BCSIR), Dhaka, Bangladesh
}

(c) The Author(s). 2017 Open Access This article is distributed under the terms of the Creative Commons Attribution 4.0 International License (http://creativecommons.org/licenses/by/4.0/), which permits unrestricted use, distribution, and reproduction in any medium, provided you give appropriate credit to the original author(s) and the source, provide a link to the Creative Commons license, and indicate if changes were made. The Creative Commons Public Domain Dedication waiver (http://creativecommons.org/publicdomain/zero/1.0/) applies to the data made available in this article, unless otherwise stated.
[6]. Previous reports involving both In vitro and in vivo studies have indicated that Saccharomyces boulardii is able to prevent intestinal infection caused by Escherichia coli, Salmonella typhimurium, Staphylococcus aureus, Pseudomonas aeruginosa, Proteus vulgaris, Yersinia enterocolitica and Candida albicans [7]. But probiotics properties of Saccharomyces cerevisiae haven't been explored that much.

Saccharomyces cerevisiae is a unicellular yeast and one of the most explored organism in terms of industrial applications and genetic studies [8]. Several previous studies showed that members of Saccharomyces genus can possess anti-bacterial and probiotic properties [9]. 
Several studies have also been reported with the use of yeasts (S. boulardii or S. cerevisiae) as a potential biotherapeutic agent (probiotic) for the treatment of microbes associated diarrhea and colitis [10]. Anti-bacterial capability of S. cerevisiae might be due to production of extracellular protease [11], secretion of inhibitory proteins, stimulation of immunoglobulin A [12], acquisition and elimination of secreted toxins [13], killer toxins, sulfur di oxide etc. [14]. Foods such as milk, fermented foods, fruits, etc. are an important source of probiotic Saccharomyces cerevisiae $[14,15]$.

No such study has been performed in Bangladesh to assess the probiotic potential of indigenous Saccharomyces cerevisiae. This study aims to determine the probiotic properties of a putative probiotic yeast strain, S. cerevisiae IFST 062013.

\section{Methods}

Isolation and identification of S. cerevisiae IFST 062013

The yeast isolates, S. cerevisiae IFST 062013 was isolated from fruit and characterized morphologically and biochemically according to Fakruddin et al. [16]. Carbohydrate (Glucose, xylose, sucrose, fructose, galactose, lactose, maltose, trehalose, ribose, rhamnose, mannitol and dextrose) utilization capability of the isolate was determined according to Forouhandeh et al. [17]. Phylogenetic identification on the basis of sequencing of highly variable region of the fungal 5.8S rDNA gene was performed as described in Fakruddin et al. [16].

\section{Stress tolerance of yeast isolate}

Sodium chloride tolerance of the yeast strains was performed according to Fakruddin et al. [18]. Sensitivity of yeast strains to oral and intestinal enzymes (lysozyme, trypsin and $\alpha$-amylase) was studied as per Nowroozi et al. [19]. In vitro survival potential of the yeast isolates in simulated gastric environment (aqueous solution containing $3 \mathrm{~g} / \mathrm{l}$ pepsin, and $5 \mathrm{~g} / \mathrm{l} \mathrm{NaCl}, \mathrm{pH} 2.0$ ) was determined according to Fietto et al. [20]. pH tolerance was determined according to Fakruddin et al. [21]. Bile salt tolerance of the isolates was investigated according to Kim et al. [22]. Thermotolerance of the yeast strains was determined according to Fakruddin et al. [14]. Organic acid production was determined according to Chowdhury et al. [4]. Antibiotic resistance of the isolate was determined by the standard agar disc diffusion technique described by Kirby-Bauer [23] and interpretation were taken from the CLSI standards [24].

\section{Probiotic properties}

Cholesterol assimilation assay was performed as per Liong and Shah [25]. Cell surface hydrophobicity and auto-aggregation ability was performed according to Syal and Vohra [26]. Activities of enzymes (amylase, protease, lipase, galactosidase and cellulase) were determined according to Kim et al. [22] and production of gelatinase and DNase was determined according to Gupta and Malik [27]. Killer toxin production was observed according to Fakruddin et al. [16]. Vitamin $\mathrm{B}_{12}$ production by the isolate was assayed according to Bishnoi et al. [28]. The reduced glutathione (GSH) content in the yeast extracts and autolysates were determined according to Hassan [29]. Siderophore production was screened according to Sourabh et al. [15]. Biofilm formation assay was performed according to Li et al. [30].

\section{Preparation of S. cerevisiae extracts and autolysates}

Yeast extracts from the yeast strains were prepared according to Ali et al. [31] and yeast autolysates were prepared according to Hassan [29].

\section{Antibacterial and anti-fungal activity}

Anti-microbial (anti-bacterial and anti-fungal) activity of whole cell was performed by agar overlay method [32] and of cell culture supernatant and cell lysate was performed by well diffusion method [33]. Antibacterial activity was further characterized by determining whether bacteriostatic or bactericidal according to Chowdhury et al. [34]. All the test isolates of bacteria and fungi were taken from culture collection pool of Industrial Microbiology Laboratory, IFST, BCSIR, Dhaka.

\section{Antioxidant and toxicity properties}

Total antioxidant capacity of yeast extracts and autolysates was assayed by the phosphomolybdenum method as described by Kumaran and Karunakaran [35]. The reducing power of yeast extracts and autolysates was determined by the method of Mathew and Abraham [36]. The antioxidant activity based on the scavenging activity of the stable DPPH free radical, was determined by the method described by Fakruddin et al. [37]. The scavenging activity of nitric oxide was determined by the method described by Kumaran and Karunakaran [35]. Hydroxyl radical scavenging activity was assayed by the method described by Nagai et al. [38]. Brine shrimp cytotoxicity assay was performed according to Fakruddin et al. [16] and acute toxicity was done according to Kabir et al. [39]. The ability of yeast extracts and autolysates to chelate ferrous ion was determined using the method described by Oboh et al. [40].

\section{Safety evaluation of S. cerevisiae IFST 062013}

Twelve swiss albino mice aged 5-6 weeks were divided into two treatment groups designated as $\mathrm{C}$ and $\mathrm{T}$ ( 6 mice in each group). In order to assess the safety of the putative probiotic isolate, S. cerevisiae IFST 062013, a single dose of $150 \mu \mathrm{l}\left(\sim 10^{9} \mathrm{cfu}\right)$ S. cerevisiae IFST 062013 were 
administered orally to each of the test group mice. Mice of the control group were fed with sterile PBS. After feeding, mice were monitored daily for 14 days to observe any changes in their activities, behavior and general health. Individual body weight was recorded daily using a balance [41]. In addition, the feces of mice were collected to enumerate the total numbers of $S$. cerevisiae and enterobacteria on day 0, 7 and 14. After 14 days. YPD agar was used for enumeration of S. cerevisiae and MacConkey agar was used for enumeration of enterobacteria [42]. Blood samples were collected for biomarker analysis, including aspartate aminotransferase (AST), alanine aminotransferase (ALT), alkaline phosphatase (ALP) and total cholesterol of the serum. Blood sample was also used to check fungaemia. The growth rate (GR), spleen weight index and liver weight ratio were calculated according to Kantachote et al. [43].

Immuno-Modulatory activity of S. cerevisiae IFST 062013 Lymphocyte proliferation assay was performed according to Ren et al. [44]. Production of cytokines (IFN- $\alpha$, IFN- $\gamma$, IL-10) was measured according to Ren et al. [44]. Gene expression of TLR-2, interferon (IFN)- $\gamma$, IL-4, Foxp3 and transforming growth factor (TGF)- $\beta$ in intestinal mucosa was determined according to Zhu et al. [45].

\section{Statistical analysis}

One way analysis of variance (ANOVA) was used to compare the results of the probiotic and control groups. Means, standard deviations and significant differences at $p$ value $<0.05$ were presented.

\section{Result}

\section{Isolation and identification}

Based on the colony characteristics (white and creamy texture) ovoid microscope shape, the presence of ascospore and budding pattern (multipolar), the selected isolate was found to belong Saccharomyces type unicellular ascomycete. Ascospores formation by the yeast isolate was detected for indication of the ascomycetous yeast. The yeast isolate can produce pseudomycelium and showed in a filamentous form under microscope and can utilize glucose, fructose, sucrose, maltose and trehalose but failed to grow on lactose and xylose, rhamnose, raffinose and arabinose, which is characteristic of Saccharomyces cerevisiae [46]. 5.8 s rDNA sequencing revealed the identity of the isolate to be Saccharomyces cerevisiae (Accession no- HM134859.1).

\section{Stress tolerance}

Stress tolerance of the S. cerevisiae IFST 062013 isolate is shown in Fig. 1. The isolate able to survive in a wide range of temperature and $\mathrm{pH}$ with optimum conditions of $37^{\circ} \mathrm{C}$ and $\mathrm{pH}$ 5.0. It can tolerate high concentration of bile salt and $\mathrm{NaCl}$, gastric juice, intestinal environment, alpha-amylase, trypsin and lysozyme. It can also produce organic acid (2.25\% after $90 \mathrm{~h}$ incubation). The isolate showed resistance to tetracycline, trimethoprimsulphamethoxazole, ampicillin, gentamycin, penicillin, nitrofurantoin, polymixin B and nalidixic acid (Fig. 1).

\section{Probiotic properties}

Probiotic properties of the isolate are shown in Table 1. The isolate can assimilate 33\% cholesterol and produced different enzymes such as amylase (84 unit/g cell), protease (1760 unit/g cell), lipase (77 unit/g cell), cellulase (39 unit/g cell) and galactosidase as well as siderophore, killer toxin and strong biofilm. It can also produce $4.48 \mathrm{mg} / 100 \mathrm{ml}$ total glutathione and $61.34 \%$ autoaggregation ability (Table 1).

\section{Antibacterial and anti-fungal activity}

Antibacterial activity of whole cells, culture supernatant and cell lysate of the isolated yeast is shown in Table 2 . Comparing with doxycycline $(30 \mu \mathrm{g} / \mathrm{disc})$, the isolate showed moderate antibacterial activity. Antifungal activity of whole cells, culture supernatant and cell lysate of the isolated yeast is shown in Table 3. Comparing with fluconazole $(100 \mu \mathrm{g} / \mathrm{disc})$, the isolate showed moderate antifungal activity. In general, cell lysate showed better anti-bacterial and anti-fungal effect. Anti-bacterial effect of the isolate was better against gram negative pathogens than gram positive.

\section{Antioxidant activity and toxicity}

Antioxidant activities and toxic properties of the isolate is shown in Fig. 2. The isolate was found to possess different beneficial activity. The isolate showed significant reducing power, DPPH scavenging activity, nitric oxide scavenging and hydroxyl radical scavenging activity (comparing with ascorbic acid). Strong brine shrimp cytotoxicity and acute toxicity was shown by the isolate (100\% lethality at $500 \mu \mathrm{g} / \mathrm{ml}$ in case of cytotoxicity and $150 \mathrm{mg} / \mathrm{kg}$ in case of acute toxicity). The chelating effect of the ferrous ions of the yeast isolate is presented in Table 4 . The isolate exhibited the ability of iron binding.

\section{Safety evaluation of S. cerevisiae IFST 062013}

There were no significant differences in general health status between probiotic fed mice and control mice (Fig. 3a). No diarrheal death was observed and no S. cerevisiae detected in blood as well. Fungaemia was not observed in blood samples of the mouse. AST, ALT and ALP content in blood were similar and cholesterol content in treated mice blood is lower than the control mice (Fig. 3b). Enterobacteria and S. cerevisiae count in the feces of treated and control mice was almost similar during the observation period (Fig. 3c). The growth rate of 


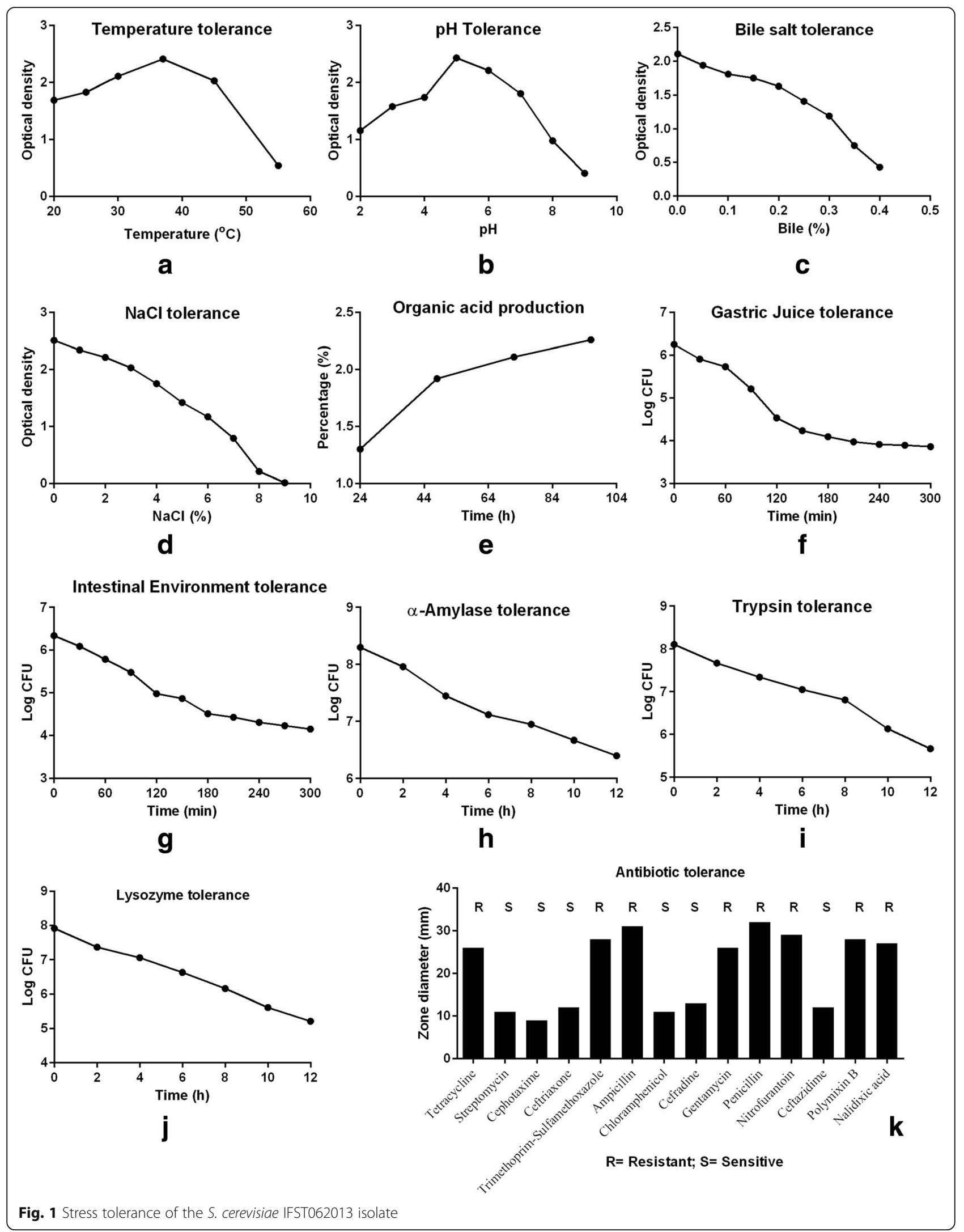


Table 1 Different probiotic properties of the yeast isolate

\begin{tabular}{lll}
\hline Property & & S. cerevisiae isolate \\
\hline Cholesterol assimilation & & $33 \%$ \\
Enzyme activity assay & amylase & 84 unit/g cell \\
& protease & $1760 \mathrm{unit} / \mathrm{g}$ cell \\
& lipase & $77 \mathrm{unit} / \mathrm{g}$ cell \\
& cellulase & $39 \mathrm{unit} / \mathrm{g}$ cell \\
Killer toxin production & + \\
total Glutathione production & $1.48 \mathrm{mg} / 100 \mathrm{ml}$ yeast \\
Galactosidase enzyme production & - \\
Production of siderophore & + \\
Biofilm formation & Strong (SBF > 1) \\
Auto-aggregation ability & $61.34 \%$ \\
\hline
\end{tabular}

treated mice found to be almost similar (difference nonsignificant) and the spleen weight index and liver weight ratio are almost similar in both groups (treated and control) (Fig. 3d).

\section{Immuno-modulatory activity}

Results indicate that the $S$. cerevisiae strain could stimulate a T-lymphocyte specific proliferative response. Proliferation index was significantly increased by the strains in a dose dependent manner (Fig. 4a). To evaluate the effects of S. cerevisiae IFST062013 on T-cell responses, the concentrations of IFN- $\alpha$, IFN- $\gamma$ and IL-10 in mouse serum were examined. There was no significant difference in the induction of IFN- $\alpha$ production during the experimental period between treated and control group (Fig. 4b). IFN- $\gamma$ levels in the serum showed no significant differences on day 10, but were, however, significantly increased by $S$. cerevisiae IFST062013 (248 pg/mL) at the higher dose $\left(5 \times 10^{9} \mathrm{CFU} /\right.$ mouse $)$ compared with the control group $(189 \mathrm{pg} / \mathrm{mL})$ on day $20(P<0.05)$. IL-10 levels were significantly increased by $S$. cerevisiae IFST062013 $(711 \mathrm{pg} / \mathrm{mL})$ at the higher dose on day 10, compared with the control group $(635 \mathrm{pg} / \mathrm{mL})(P<0.05)$, but a more prominent effect was found for probiotic treated group $751 \mathrm{pg} / \mathrm{mL}$ ) compared with the control group $(637 \mathrm{pg} / \mathrm{mL})$ on day $20(P<0.01)$. Gene expression of cytokines (TLR-2, IFN- $\gamma$, IL-4, Foxp3 and TGF- $\beta$ ) in intestinal mucosa was determined. Expression of TLR-2 and IFN- $\gamma$ was increased in mice treated the isolate in a dose dependent manner. In contrary, the expression of Foxp3, TGF- $\beta$ and IL-4 was decreased (Fig. 4e).

\section{Discussion}

Saccharomyces cerevisiae is one of the most studied microorganisms and for long has been used in different biotechnological applications due to its better fermentation capability. Besides industrial applications, probiotic and health benefit potential of yeast has also been reported in recent times [47]. Probiotics are defined as the viable microorganisms that exhibit a beneficial effect on health of the host by improving its intestinal microbial balance. S. cerevisiae and S. boulardii are clinically proven yeasts being used as a human probiotic and has shown to positively influence host's health by antimicrobial effect, nutritional effect, inactivation of bacterial toxins, quorum sensing, trophic effects, immuno-modulatory effects, anti-inflammatory effects, cell restitution and maintenance of epithelial barrier integrity [48].

Table 2 Antibacterial activity of the yeast isolate

\begin{tabular}{|c|c|c|c|c|c|c|}
\hline \multirow[t]{3}{*}{ Test organism } & & \multirow[t]{3}{*}{ Source ID (ATCC) } & \multicolumn{4}{|c|}{ Zone diameter (mm) } \\
\hline & & & \multicolumn{3}{|c|}{ Yeast isolate } & \multirow[t]{2}{*}{ Doxycycline } \\
\hline & & & Whole cell & Culture supernatant & Cell lysate & \\
\hline \multirow[t]{6}{*}{ Gram positive } & B. subtilis & 11774 & 7 & 5.1 & 11.6 & 21 \\
\hline & S. aureus & 25923 & 7.5 & 4.9 & 10.3 & 24 \\
\hline & B. cereus & 10876 & 7 & 6.1 & 9.4 & 12 \\
\hline & B. polymyxa & 842 & 8.5 & 5.9 & 11.4 & 21 \\
\hline & B. megaterium & 13578 & 7 & 5.4 & 9.8 & 28 \\
\hline & E. faecalis & 29212 & 6.5 & 5.3 & 10.4 & 19 \\
\hline \multirow[t]{7}{*}{ Gram negative } & S. typhi & 65154 & 11.5 & 8.3 & 14.8 & 27 \\
\hline & S. flexneri & 12022 & 12.0 & 7.9 & 15.2 & 15 \\
\hline & K. pneumoniae & 13883 & 10.5 & 7.5 & 13.7 & 22 \\
\hline & P. vulgaris & 13315 & 10 & 8.1 & 15.1 & 17 \\
\hline & E. coli & 25922 & 11 & 8.7 & 14.9 & 19 \\
\hline & V. cholerae & 15748 & 13.5 & 9.6 & 16.3 & 26 \\
\hline & P. aeruginosa & 27853 & 12.5 & 9.1 & 16.1 & 21 \\
\hline
\end{tabular}


Table $\mathbf{3}$ In-vitro antifungal activity of CHET and fluconazole

\begin{tabular}{|c|c|c|c|c|c|}
\hline \multirow[t]{3}{*}{ Organism } & \multirow[t]{3}{*}{ Source ID (DSM) } & \multicolumn{4}{|c|}{ Zone diameter (mm) } \\
\hline & & \multicolumn{3}{|c|}{ Yeast } & \multirow[t]{2}{*}{ Fluconazol } \\
\hline & & Whole cell & Culture supernatant & Cell lysate & \\
\hline A. ustus & 63535 & 16.5 & 14.6 & 19.5 & 45 \\
\hline A. niger & 737 & 27.2 & 24.3 & 33.4 & 65 \\
\hline A. ochraceus & 824 & 21.6 & 18.4 & 24.1 & 41 \\
\hline P. chrysogenum & 1075 & 23.5 & 19.7 & 25.3 & 48 \\
\hline R. oryzae & 2200 & 19.7 & 17.5 & 22.7 & 46 \\
\hline
\end{tabular}

In this study a potential probiotic yeast strain $(S$. cerevisiae IFST 062013) was isolated from fruit and identified and characterized as Saccharomyces cerevisiae on the basis of morphological and biochemical characteristics and phylogenetic analysis. Many other studies reported probiotic yeast isolated from different samples
[5, 14, 15, 49, 50]. Al Zubaidy and Khidhr [51] also identified Saccharomyces cerevisiae var. bouldardii from fruits with probiotic properties (antimicrobial activity, bile salt and gastric acid tolerance). Syal and Vohra [52] reported probiotic attributes of Geotrichum klebahnii, a yeast like fungus isolated from cheese.

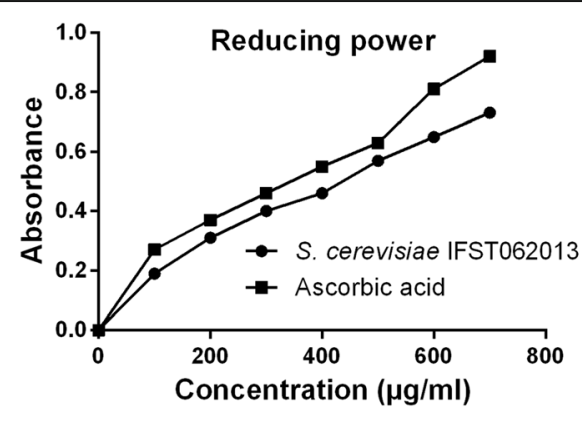

a

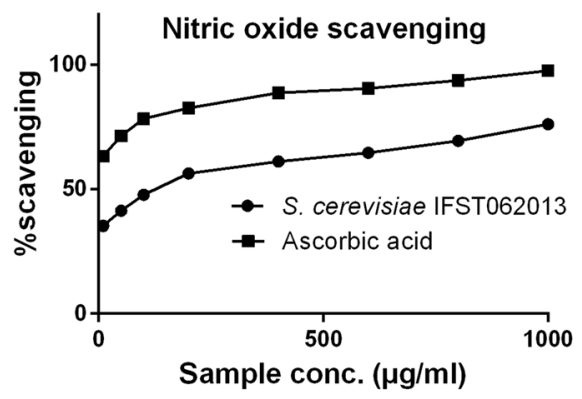

C

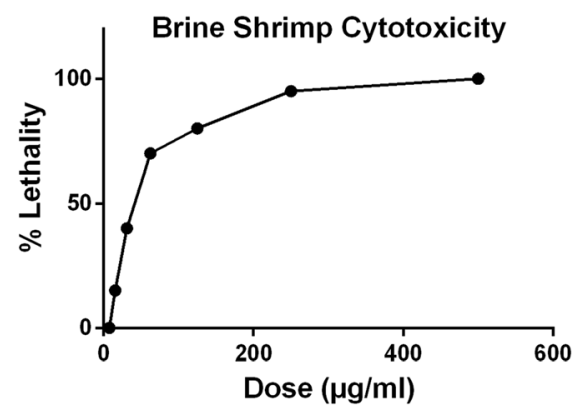

e

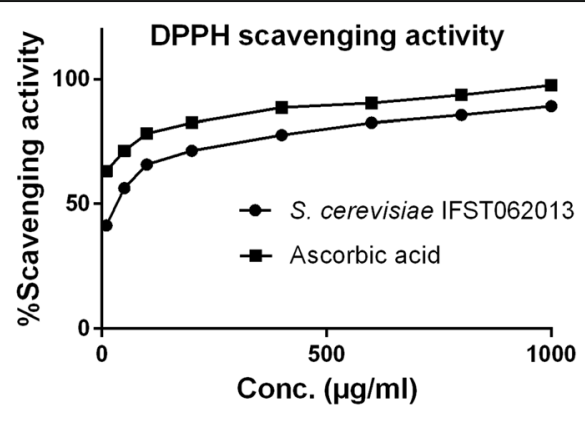

b

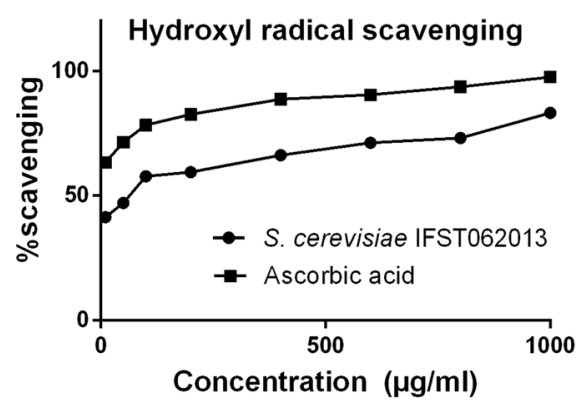

d

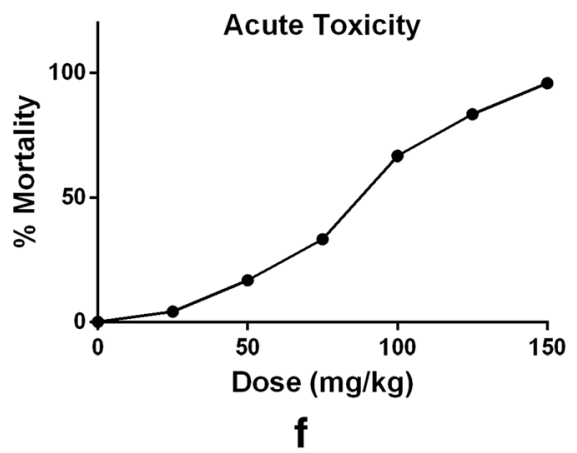

Fig. 2 Pharmacological activity of the S. cerevisiae IFST062013 isolate 
Table 4 Ferrous iron chelation of yeast isolate and EDTA

\begin{tabular}{lccc}
\hline SL & $\begin{array}{l}\text { Sample concentration } \\
(\mathrm{mg} / \mathrm{ml})\end{array}$ & \% Fe Chelation & \\
\cline { 3 - 4 } & 2.5 & Standard EDTA & Yeast isolate \\
\hline 1 & 3.5 & $67.86 \pm 1.11$ & $13.84 \pm 0.97$ \\
2 & 4.5 & $76.15 \pm 1.42$ & $23.42 \pm 0.68$ \\
3 & 5.5 & $86.34 \pm 1.69$ & $28.33 \pm 1.43$ \\
4 & 6.5 & $91.25 \pm 0.75$ & $33.77 \pm 1.85$ \\
5 & Values
\end{tabular}

Values are expressed as mean \pm SD of three parallel measurements

To be a successful probiotic, any microorganisms must have the capability to be tolerant to stresses that prevail inside human body. The isolate can grow in a wide range of temperature and $\mathrm{pH}$ while optimum growth at $37^{\circ} \mathrm{C}$ and $\mathrm{pH}$ 5.0. It also possesses tolerance to bile salt, high $\mathrm{NaCl}$, simulated gastric juice, intestinal environment, $\alpha$ amylase, trypsin and lysozyme (Fig. 1). Syal and Vohra [26] reported yeast isolates that can survive in low $\mathrm{pH}$ and high bile salt concentration. It can produce organic acid and showed resistance against tetracycline, ampicillin, gentamycin, penicillin, polymixin B and nalidixic acid. The resistance of the yeast strain to antibiotics make it suitable for use in patients undergoing antibiotic treatment [52]. Higher resistance to antibiotic provides the yeast strain advantage over bacteria for therapeutic use.

The isolate pose desirable properties to be a potential probiotic. It can assimilate cholesterol (33\%), can produce killer toxin, vitamin B12, glutathione, siderophore and strong biofilm. Vitamins play key role in numerous metabolic processes of the body and yeasts have been reported to be able to produce vitamins, especially vitamin B complex, which is a distinctive advantage for yeast to be used as a probiotic over bacteria [52]. Dubash et al. [53] reported a number of yeast strains belonging to Sachharomyces cerevisiae, Candida pintolopesii, Candida tropicalis, Pichia anomala and Dekkera spp. with killer toxin activity. It showed moderate autoaggregation ability and cell surface hydrophobicity. Auto-aggregation and cell surface hydrophobility is very important property of a potential probiotic as these properties are involved in adhesion of the microorganisms to intestinal epithelial cells of patients [54]. To provide health benefits to patients by improving nutrient utilization within the intestine, a probiotic should have the ability to produce related enzymes [55]. The isolate can produce enzymes such as amylase, protease, lipase, cellulose, but unable to produce galactosidase. The isolate don't produce gelatinase and DNase indicating its safety to be used for human patients as most of the pathogenic microorganisms produce these enzymes as part of their pathogenesis [26]. Cholesterol assimilation by yeast with probiotic attributes has also been reported by Chen et al. [53]. Syal and Vohra [26] reported yeast isolates that showed high auto-aggregation ability and cell surface hydrophobicity. The isolates were able to produce enzymes such as phytase, $\beta$-galactosidase, $\mathrm{L}$-asparaginase, protease and lipase. The isolates can produce vitamin $\mathrm{B} 12$ and exopolysaccharide. The isolates can assimilate cholesterol, don't produce DNase

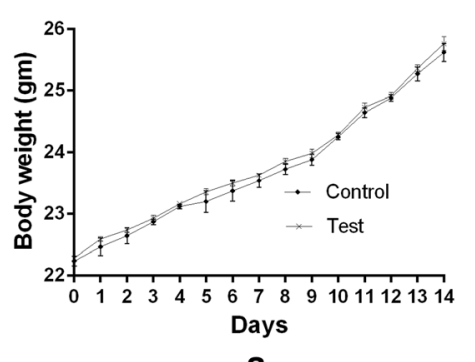

a
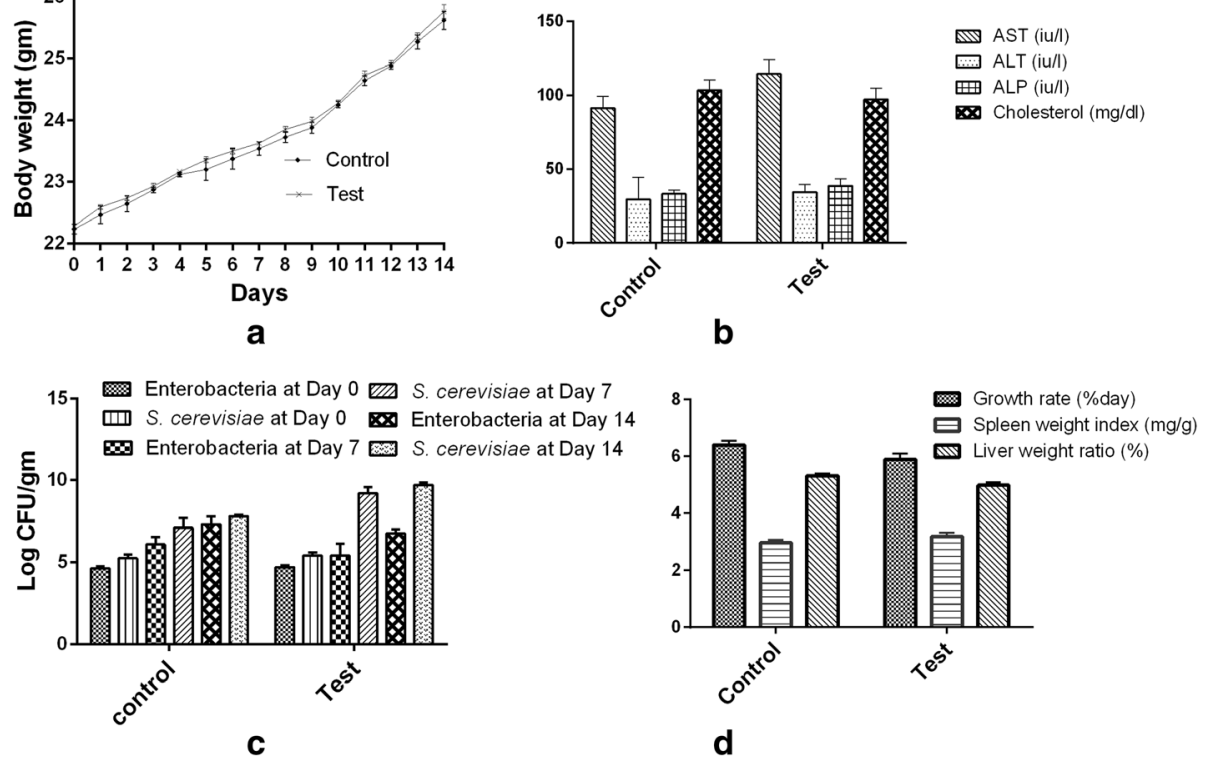

Fig. 3 Safety evaluation of S. cerevisiae IFST 062013 in mice. a comparison of body weight; b comparison of AST, ALP, ALT and cholesterol level; c Enterobacteria and S. cerevisiae count in the feces; $\mathbf{d}$ comparison of liver weight and spleen weight ratio of treated and control mice 


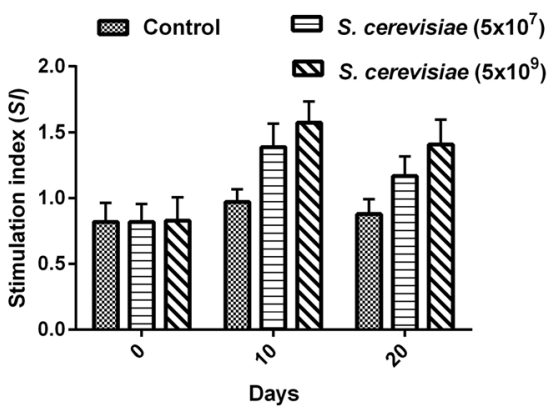

a

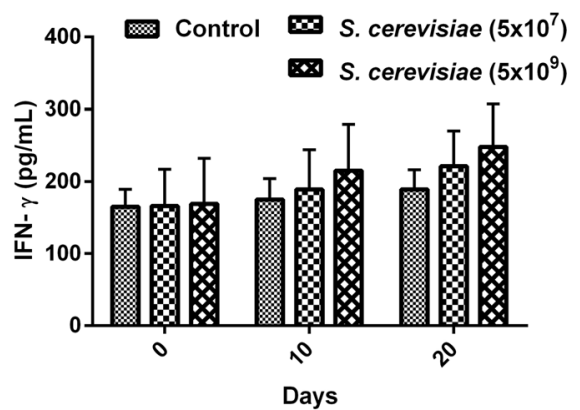

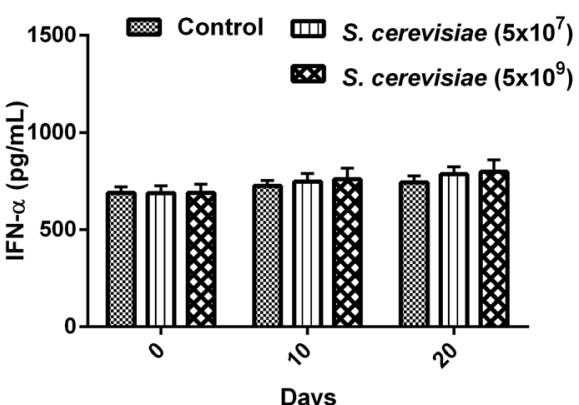

b

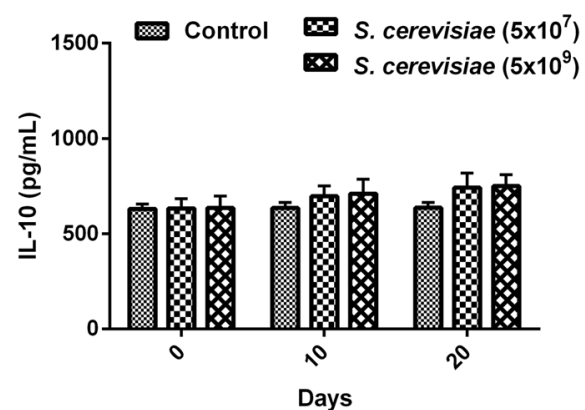

d

C

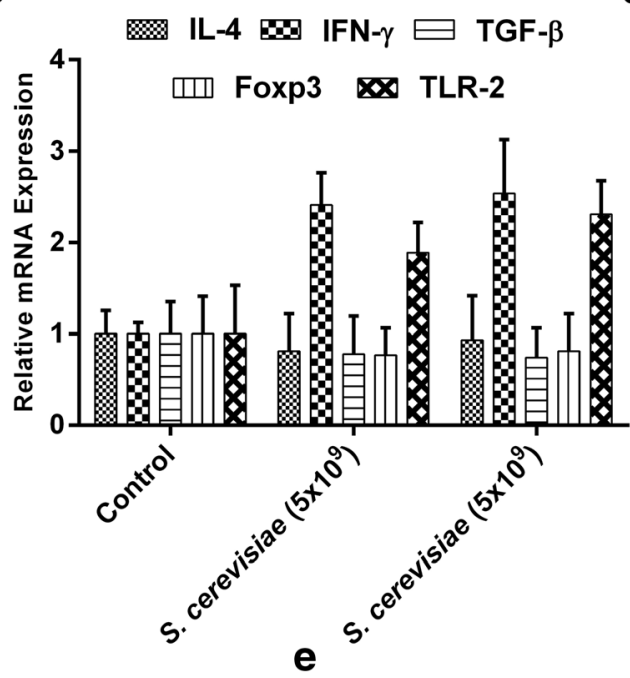

Fig. 4 Immuno-modulatory activity of the S. cerevisiae IFST062013. a T-lymphocyte proliferation; b IFN-a, c IFN- $\gamma$, $\mathbf{d}$ IL-10 production in serum of treated and control mice; e Gene expression of cytokines (TLR-2, IFN- $\gamma$, IL-4, Foxp3 and TGF- $\beta$ ) in intestinal mucosa

and gelatinase. Sourabh et al. [15] reported probiotic yeast with surface hydrophobicity and autoaggregation.

One of the most desirable properties of probiotic yeasts is the anti-bacterial activity of yeasts against human pathogens. The isolate showed moderate antimicrobial activity against bacteria and fungi in comparison with standard antibiotic (Doxycycline for bacteria and fluconazole for fungi). Cell lysate showed better antimicrobial activity than whole cell and culture supernatant. Again, the isolate showed better anti-bacterial activity against gram negative bacteria than gram positive. Culture supernatant showed least antimicrobial activity indicating that the anti-microbial compounds are not extracellular, rather cell bound. Rajkowska et al. [56] reported probiotic yeast strains (belonging to $S$. cerevisiae and $S$. boulardii) which showed antagonistic activity against human pathogens such as Listeria monocytogenes, Salmonella typhimurium, Pseudomonas aeruginosa, Escherichia coli and Enterococcus faecalis. Roostita et al. [14] reported yeast strains with antimicrobial activity against Pseudomonas aerugenes, Staphylococcus aureus and Escherichia coli. 
Syal and Vohra [26] isolated yeast with antimicrobial activity against E. coli, Salmonella sp., Staphylococcus aureus, Vibrio cholerae and Pseudomonas sp. Further studies on antimicrobial activity of the yeast isolate against other species of pathogenic bacteria and fungi are needed.

The isolate showed strong antioxidant activity, reducing power, nitric oxide and hydroxyl radical scavenging activity, significant brine shrimp cytotoxicity and acute toxicity (Fig. 2) and metal ion chelating activity (Table 4). Foligne et al. [42] reported yeast possessing significant anti-inflammatory activity in mice. Antioxidant activity of yeast has also been reported by Chen et al. [54]. Hassan [29] reported two yeast isolate, whose cell autolysates showed antioxidant and immunostimulating activity such as reducing power, DPPH radical scavenging, nitric oxide scavenging, hydroxyl radical scavenging and metal ion chelating activities. Sourabh et al. [15] reported probiotic yeast with antioxidant properties, DPPH free radical scavenging activity and siderophore production ability. The isolate also showed strong metal chelating activity, an essential property for antioxidant activity. Hassan [29] has reported probiotic Saccharomyces cerevisiae with strong metal ion chelating activity.

Safety assessment is an important criterion to select any potential probiotic for therapeutic applications. To assess the safety of S. cerevisiae IFST 062013, oral toxicity testing in mice was conducted. After 14 days of post-ingestions period, there were no significant differences in behavior or activity of the mice and no diarrheal death. No $S$. cerevisiae was detected in blood samples which indicate that the isolate don't pose the ability to infiltrate areas outside the intestine. AST level provides a general estimation about any cellular injury occurred as its level increases in case of disease \& cellular injury. On the other hand, ALT more specifically indicates liver cell damage \& higher serum cholesterol. Increased ALP has been linked with increased osteoblastic activity \& lack of bile flow \& higher serum cholesterol [41]. Blood sample analysis also showed that AST, ALP and ALT content is almost similar in both treated and control group mice. But cholesterol content in treated group mice were lower than control group mice further ensuring the isolate's ability to assimilate cholesterol. These observations indicate that the isolate do not induce any gross acute oral toxicity on general health, growth and development of mice. There were no significant differences in numbers of enterobacteria and $S$. cerevisiae in the feces of treated group and control group mice throughout the 14 day observation period, which indicate that the isolate can persist in the intestines. Growth rate of the treated group mice was almost similar to that of the control mice. There were no significant difference between spleen weight index and liver weight ratio of the treated group and control group mice. These results indicate that the isolate cannot induce any systemic infections in mice and is non-invasive.

To test the effect of S. cerevisiae IFST062013 on the cellular immune response, we examined splenocyte proliferation. On day 10, the spleen lymphocyte proliferation capacity was significantly increased in the $S$. cerevisiae-treated groups when compared with the ConA control group $(P<0.04)$. The SI values of the higher dose groups $\left(5 \times 10^{9} \mathrm{CFU} /\right.$ mouse $)$ reached their maximum values and were higher than for the moderate dose groups $\left(5 \times 10^{8} \mathrm{CFU} /\right.$ mouse $)(P<0.01)$. On day 20 , the results showed a similar trend. These results indicate that the probiotic $S$. cerevisiae strain could stimulate a T-lymphocyte specific proliferative response and could potentiate humoral immunity and cell-mediated immunity and consequently have potential antitumor activity. Cytokines play an important role in the development of immune response, we evaluated the effect of the strain on the production of pro-inflammatory cytokines IFN- $\alpha$ and IFN- $\gamma$, and the anti-inflammatory cytokine IL-10. IFN- $\gamma$ induces cell-mediated and inflammatory immune responses. Our results showed that the probiotic strain simultaneously induced pro- and anti-inflammatory mediators and consequently helped to maintain a balance between Th1 and Th2 type cytokines, which is important for host immunity. The probiotic strain modulates gene expression of cytokines in dose dependentmanner (Fig. 4).

\section{Conclusion}

The Saccharomyces cerevisiae IFST 062013 isolate showed promising probiotic activities and possessed comparable attributes with other reported probiotic yeasts. Continuous screening for selection of probiotic strains with even better attributes should be carried out. Before therapeutic application, further research should be done to ensure safety and efficiency of the potential probiotic yeast.

\section{Abbreviation \\ ALP: Alkaline phosphatase; ALT: Alanine aminotransferase; AST: Aspartate aminotransferase; Cfu: Colony forming unit; CLSI: Clinical and Laboratory Standards Institute; DNA: Deoxyribo nucleic acid; DPPH: 2,2-diphenyl-1- picrylhydrazyl; GSH: Glutathione; PBS: Phosphate buffered saline; PCR: Polymerase chain reaction; YPD: Yeast extract-Peptone-Dextrose agar; $\mu \mathrm{g}$ : Micro gram}

\section{Acknowledgement}

We acknowledge the help of Mr. Mizanur Rahaman, Research Fellow, Industrial Microbiology Laboratory, IFST, BCSIR in conducting this research.

Funding

No funding received.

Availability of data and materials

All data are incorporated in the paper. 


\section{Authors' contribution}

MF planned the study. MF and MN performed all the experiments. MMA provides necessary advices and guidelines in conducting the work. MF wrote the first draft of the manuscript and all authors read and approved the final manuscript.

\section{Competing interests}

The authors declare that they have no competing interests.

\section{Consent for publication}

Not applicable.

\section{Ethical approval and consent to participate}

Experimental protocols approved by BCSIR institutional ethical review committee were followed while performing research with mice.

\section{Received: 27 August 2015 Accepted: 17 January 2017}

\section{Published online: 21 January 2017}

\section{References}

1. Kechagia M, Basoulis D, Konstantopoulou S, Dimitriadi D, Gyftopoulou K, Skarmoutsou N, Fakiri EM. Health benefits of probiotic- A review. ISRN Nutr. 2013. Article ID: 481651.

2. Reid G. Probiotic agents to protect the urogenital tract against infection. Am J Clin Nutr. 2001:73(2):437-43.

3. Kopp MV, Ankermann T, Härtel C. Clinical potential for the use of probiotics in the management of respiratory conditions \& cold- and influenza-like symptoms. Nutr Diet Suppl. 2011;3:51-8.

4. Chowdhury A, Hossain MN, Mostazir NJ, Fakruddin M, Billah MM, Ahmed MM. Screening of Lactobacillus spp from Buffalo yoghurts for Probiotic and Antibacterial Activity. J Bacteriol Parasitol. 2012;3(8):156

5. Rajkowska K, Kunicka-Styczynska A. Probiotic properties of yeasts isolated from chicken feces and kefirs. Polish J Microbiol. 2010;59(4):257-63.

6. Soccol CR, Vandenberghe LPS, Spier MR, Medeiros ABP, Yamaguishi CT, Lindner JDD, Pandey A, Thomaz-Soccol V. The potential of probiotics: A review. Food Technol Biotechnol. 2010:48(4):413-34.

7. Czerucka D, Rampal P. Experimental effects of Saccharomyces boulardii on diarrheal pathogens. Microbes Infect. 2002;4:733-9.

8. Branduardi P, Smeraldi C, Porro D. Metabolically engineered yeasts: 'Potential' industrial applications. J Mol Microbiol Biotechnol. 2008;15:31-40.

9. Nayak SK. Biology of eukaryotic probiotics. In: Liong M-T, editor. Probiotics. Berlin: Springer; 2011. p. 29-55.

10. Kelsesidis T, Pothoulakis C. Efficacy and safety of the probiotic Saccharomyces boulardii for the prevention \& therapy of gastrointestinal disorders. Ther Adv Gastroenterol. 2012;5(2):111-25.

11. Roostita LB, Fleet GH, Wendry SP, Apon ZM, Gemilang LU. Determination of yeasts antimicrobial activity in milk and meat products. Adv J Food Sci Technol. 2011;3(6):442-5.

12. Qamar A, Aboudola S, Warny M, Michetti P, Pothoulakis C, LaMont JT, et al. Saccharomyces boulardii stimulates intestinal immunoglobulin $A$ response to Clostridium difficile toxin A in mice. Infect Immun. 2001;69:2762-5.

13. Fooks $\sqcup$, Gibson GR. Probiotics as modulators of the gut flora. Br J Nutr. 2002;88:39-49.

14. Roostita LB, Fleet GH, Wendry SP, Apon ZM, Gemilang LU. Determination of Yeasts Antimicrobial Activity in Milk and Meat Products. Adv J Food Sci Technol. 2011;3(6):442-5.

15. Sourabh A, Kanwar SS, Sharma OP. Screening of indigenous yeast isolates obtained from traditional fermented foods of Western Himalayas for probiotic attributes. J Yeast Fungal Res. 2011;2(8):117-26.

16. Fakruddin M, Islam MA, Quayum MA, Ahmed MM, Chowdhury N Characterization of stress tolerant high potential ethanol producing yeast from agro-industrial waste. Am J Biosci. 2013;1(2):24-34.

17. Forouhandeh $H$, Vahed AZ, Hejazi MS, Nahaei MR, Dibavar MA. Isolation and phenotypic Characterization of Lactobacillus species from various dairy products. Curr Res Bacteriol. 2010;3(2):84-8.

18. Fakruddin M, Islam MA, Quayum MA, Ahmed MM, Chowdhury N. Process optimization of bioethanol production by stress tolerant yeasts isolated from agro-industrial waste. Intl J Renew Sustain Energy. 2013;2(4):133-9.

19. Nowroozi J, Mirzaii M, Norouzi M. Study of Lactobacillus as probiotic bacteria. Iranian J Publ Health. 2004;33(2):1-7.
20. Fietto JLR, Araújo RS, Valadão FN, Fietto LG, Brandão RL, Neves MJ, Gomes FCO, Nicoli JR, Castro IM. Molecular and physiological comparisons between Saccharomyces cerevisiae and Saccharomyces boulardii. Can J Microbiol. 2004:50:615-21.

21. Fakruddin M, Rahman MM, Ahmed MM, Hoque MM. Stress tolerant virulent strain of Cronobacter sakazakii from food. Biol Res. 2014:47:63.

22. Kim S, Kim H, Chae HJ. Selection of probiotic yeasts from soil, characterization and application for feed additives. Agric Chem Biotechnol. 2004;47(1):20-6.

23. Bauer AW, Kirby WM, Sheris JC, Turck M. Antibiotic susceptibility testing by a standardized single disc method. Am J Clin Path. 1966;45:493-6.

24. CLSI. Performance standards for Antimicrobial Susceptibility Testing. 16th Informational Supplement. (CLSI document M100-S16). 2006

25. Liong MT, Shah NP. Acid and bile tolerance and cholesterol removability of lactobacilli strains. J Dairy Sci. 2005;88:55-66.

26. Syal $P$, Vohra A. Probiotic potential of yasts isolated from traditional indian fermented foods. Intl J Microbiol Res. 2013:5(2):390-8.

27. Gupta $H$, Malik RK. Incidence of virulence in bacteriocin-producing enterococcal isolates. Lait. 2007:87:587-601.

28. Bishnoi K, Mahesh K, Vipin S, Deepika G. Microbiological assay for vitamin B. Intl Res J Pharm. 2012:3(2):74-82.

29. Hassan HMM. Antioxidant and immunostimulating activities of Yeast (Saccharomyces cerevisiae) autolysates. World Appl Sci J. 2011;15(8):1110-9.

30. Li X, Yan Z, Xu J. Quantitative variation of biofilms among strains in natural populations of Candida albicans. Microbiol. 2003:149:353-62.

31. Ali MAE, Abdel-Fatah OM, Janson J-C, Elshafei AM. Antimicrobial potential of Saccharomyces boulardii extracts and fractions. J Appl Sci Res. 2012;8(8):4537-43.

32. Aween MM, Hassan Z, Muhialdin BJ, Noor HM, Eljamel YA. Evaluation on Antibacterial Activity of Lactobacillus acidophilus Strains Isolated from Honey. Am J Appl Sci. 2012;9(6):807-17.

33. Sowani HM, Thorat P. Antimicrobial Activity Studies of Bactoriocin produced by Lactobacilli Isolates from Carrot Kanji. Online J Biol Sci. 2012;12(1):6-10.

34. Chowdhury A, Malaker R, Hossain MN, Fakruddin M, Noor R, Ahmed MM. Bacteriocin profiling of probiotic Lactobacillus spp. isolated from yoghurt. Intl J Pharma Chem. 2013;3(3):50-6

35. Kumaran A, Karunakaran RJ. In vitro antioxidant activities of methanol extracts of five Phyllanthus species from india. LWT-Food Sci Technol. 2007:40(2):344-52

36. Mathew S, Abraham TE. Studies on the antioxidant activities of cinnamon (Cinnamomum verum) bark extracts, through various in vitro models. Food Chem. 2006;94:520-8.

37. Fakruddin M, Mannan KSB, Mazumdar RM, Afroz H. Antibacterial, antifungal and antioxidant activities of the ethanol extract of the stem bark of Clausena heptaphylla. BMC Complement Alt Med. 2012;12:232.

38. Nagai T, Inoue R, Suzuki N, Myoda T, Nagashima T. Antioxidative ability in a linoleic acid oxidation system and scavenging abilities against active oxygen species of enzymatic hydrolysates from pollen Cistus ladaniferus. Int| J Mol Med. 2005;15(2):259-63.

39. Kabir MG, Rahman M, Ahmed NU, Fakruddin M, Islam S, Mazumdar RM. Antioxidant, antimicrobial, toxicity and analgesic properties of ethanol extract of Solena amplexicaulis root. Biol Res. 2014:47:36.

40. Oboh G, Puntel RL, Rocha JBT. Hot papper (Capsicum annuum, Tepin and Capsicum chinese, Habanero) prevents Fe2 + -induced lipid peroxidation in brain in vitro. Food Chem. 2007;102(1):178-85.

41. Oyetayo VO, Adetuyi FC, Akinyosoye FA. Safety and protective effect of Lactobacillus acidophilus and Lactobacillus casei used as probiotic agent in vivo. Afr J Biotechnol. 2003;2(11):448-52.

42. Foligne B, Dewulf J, Vandekerckove P, Pignede G, Bruno P. Probiotic yeasts: Anti-inflammatory potential of various non-pathogenic strains in experimental colitis in mice. World J Gastroenterol. 2010;16(17):2134-45.

43. Kantachote D, Prachyakij P, Charernjiratrakul W, Ongsakul M, Duangjitcharoen Y, Chaiyasut C, Nitoda T, Kanzaki H. Characterization of the anti-yeast compound and probiotic properties of a starter Lactobacillus plantarum DW3 for possible use in fermented plant beverages. Electronic J Biotechnol. 2010;13(5):1-15.

44. Ren D, Li C, Qin Y, Yin R, Du S, Liu H, Zhang Y, Wang C, Rong F, Jin N. Evaluation of immunomodulatory activity of two potential probiotic Lactobacillus strains by in vivo tests. Anaerobe. 2015;35:22-7.

45. Zhu Y, Zhu J, Zhao L, Zhang M, Guo H, Ren F. Effect of oral administration of lactobacillus paracasei 19 on mouse Systemic immunity and the immune response in the intestine. Arch Biol Sci. 2016;68(2):311-8. 
46. Boekhout T, Kurtzman CP. Principles and methods used in yeast classification, and an overview of currently accepted yeast genera. In: Wolf K, editor. Nonconventional Yeasts in Biotechnology: A Handbook. Heidelberg: Springer; 1996. p. 1-99.

47. Fijan S. Microorganisms with Claimed Probiotic Properties: An Overview of Recent Literature. Int J Environ Res Public Health. 2014;11:4745-67.

48. Moslehi-Jenabian $S$, Pedersen $L L$, Jespersen $L$. Beneficial Effects of Probiotic and Food Borne Yeasts on Human Health. Nutrients. 2010;2:449-73.

49. Pennacchia C, Blaiotta G, Pepe O, Villani F. Isolation of Saccharomyces cerevisiae strains from different food matrices and their preliminary selection for a potential use as probiotics. J Appl Microbiol. 2008;105:1919-28.

50. Candrawati DPMA, Warmadewi DA, Bidura I. Isolation of Saccharomyces Spp from Manure of Beef Bali Cattle as a Probiotics Properties and has CMC-ase Activity to Improve Nurient Quality of Rice Bran. J Biol Chem Res. 2014;31(1):39-52.

51. Al Zubaidy ZA, Khidhr KO. Isolation and Identification of Saccharomyces cerevisiae var boulardii and its Uses as a Probiotic (in vitro). Raf J Sci. 2014;25(1):1-11.

52. Syal P, Vohra A. Probiotic attributes of a yeast-like fungus, Geotrichum klebahnii. Afr J Microbiol Res. 2014;8(20):2037-43.

53. Dubash T, Gupta S, Prakash PY, Bairy I. Isolation of Yeasts from Various Food Products and Detection of Killer Toxin Activity In vitro. J Sci Res. 2010;2(2):407-11.

54. Chen L-S, Ma Y, Chen L-J, Zhao C-H, Maubois J-L, Jiang T-M, Li H-M, He S-H. Antioxidant activity of two yeasts and their attenuation effect on 4nitroquinoline 1-oxide induced in vitro lipid peroxidation. Intl J Food Sci Technol. 2010;45:555-61.

55. Chen L-S, Ma Y, Maubois J-L, He S-H, Chen L-J, Li H-M. Screening for the potential probiotic yeast strains from raw milk to assimilate cholesterol. Dairy Sci Technol. 2010;90:537-48.

56. Rajkowska K, Kunicka-Styczynska A, Rygala A. Probiotic Activity of Saccharomyces cerevisiae var. boulardii Against Human Pathogens. Food Technol Biotechnol. 2012;50(2):230-6.

\section{Submit your next manuscript to BioMed Central} and we will help you at every step:

- We accept pre-submission inquiries

- Our selector tool helps you to find the most relevant journal

- We provide round the clock customer support

- Convenient online submission

- Thorough peer review

- Inclusion in PubMed and all major indexing services

- Maximum visibility for your research

Submit your manuscript at www.biomedcentral.com/submit
Biomed Central 